Journal of Epidemiology and Public Health (2019), 4(1): 30-36

https://doi.org/10.26911/jepublichealth.2019.04.01.04

\title{
Socioeconomic Determinants of Healthy Ageing and the Contextual Effect of Peer Group: A Multilevel Evidence from Blora, Central Java
}

\author{
Niena Ayu Cahyaningtyas'), Aris Sudiyanto'), RB. Soemanto3) \\ ${ }^{1)}$ Masters Program in Public Health, Universitas Sebelas Maret \\ 2)Department of Psychiatry, Faculty of Medicine, Universitas Sebelas Maret \\ 3)Faculty of Social and Political Sciences, Universitas Sebelas Maret
}

\begin{abstract}
Background: Healthy ageing is about "optimizing opportunities for good health, so that older people can take an active part in society and enjoy an independent and high quality of life". This study aimed to examine the socioeconomic determinants of healthy ageing and the contextual effect of peer group in Blora, Central Java.

Subjects and Method: This was a cross-sectional study conducted in Blora, Central Java.A sample of 200 elderly was selected for this study by snowball sampling. The dependent variable was healthy ageing. The independent variables were nutrition intake, age, religiosity, education, and perceived financial position. Data on healthy ageing was collected by WHOQOL-BREF. The other variables were measured by questionnaire. The data were analyzed by a multilevel model.

Results: Healthy ageing was positively affected by strong religous belief $(b=6.75 ; 95 \% \mathrm{CI}=3.91$ to 9.59; $\mathrm{p}<0.001)$, better education $(\mathrm{b}=8.16 ; 95 \% \mathrm{CI}=4.26$ to $12.07 ; \mathrm{p}<0.001)$, better perceived financial position $(\mathrm{b}=6.46 ; 95 \% \mathrm{CI}=2.86$ to $10.07 ; \mathrm{p}<0.001)$, and good nutritional status $(\mathrm{b}=6.79$; $95 \% \mathrm{CI}=3.76$ to $9.83 ; \mathrm{p}<0.001)$.
\end{abstract}

Conclusion: Healthy ageing is positively affected by strong religous belief, better education, better perceived financial position, and good nutritional status.

Keywords: healthy ageing, religious belief, elderly, ageing, peer support group

\section{Correspondence:}

Niena Ayu Cahyaningtyas. Masters Program in Public Health, Universitas Sebelas Maret, J1 Ir. Sutami 36A, Surakarta 57126, Central Java. Email: niena.ayu21@gmail.com.

Mobile: 085640776171

\section{BACKGROUND}

Socio-economic development in almost all countries was followed by a significant increase in Life Expectancy (UHH), especially between 2000-2015 (Venkatapuram et al., 2017). This phenomenon leads to rapid changes in the demographics of the population in the world, namely the proportion of elderly people who increase drastically in a short period of time (WHO, 2017; Tosato et al., 2007). The occurrence of an epidemiological transition in the health sector because of the increase in the elderly population which results in an increase in the number of morbiditydue to this disease also occurs in Indonesia (Pusdatin Kemenkes RI, 2013; Help Age International, 2015).

The population in the elderly group is predicted to increase from 841 million in 2013 to more than 2 billion in 2050, this proportion is almost two times the world's population, from $11.7 \%$ in 2013 to $21.1 \%$ in 2050. The elderly population in Indonesia is not equally distributed but is mostly located in the provinces of East Java, Central Java and West Java (Cao and Rammohan, 2016). 
Indonesia has problems in the lack of social safety networks, inadequate health infrastructure, trust in families about old age guarantees (Cao $\mathrm{J}$ and Rammohan A, 2016). The situation in Indonesia today is that there are still many elderly people living in poverty, only $25 \%$ of the elderly population receive pension funds, while $75 \%$ of those working in the non-formal sector do not have any old age insurance. Elderly also experience injustice in income, access to education, fulfillment of health needs at work which results in low social security, even in certain cultures, lack of involvement in managing finances and rejection of property rights and inheritance of property (UNDP, HelpAge International, AARP, 2017). Elderly population morbidity rate in 2014 of $25.05 \%$ means that out of every 100 elderly people, there are 25 of them experiencing illness (Central Statistics Agency, Susenas 2005-2014).

Qualified and healthy elderly refers to WHO's concept of healthy aging, which is an aging process that remains healthy physically, socially and mentally so that it can remain prosperous throughout life and continue to participate in order to improve the quality of life as a member of the community (Pusdatin of the Ministry of health, 2016). WHO uses a lifelong approach to promote healthy aging.

There are many kinds of determinants of health. All of these factors have a significant impact on health, especially social determinants. The area of social determinants of health is focused on key aspects of a person's lifestyle, life and work environment (Didem et al., 2012). Socioeconomic factors are a key influence on health, and their effects on death and on life expectancy free from disability in old age (Rothenberg et al., 1991; Fried and Guralnik, 1997; Stuck et al., 1999 in Jang et al., 2009). White et al. (2015) also stated that socioeconomic factors have a strong relationship with health.

Based on the description of the facts above, this study aims to analyze socioeconomic determinants and peer group influence on Healthy Aging.

\section{SUBJECTS AND METHOD}

\section{Study Design}

This was an analytic observational study with a cross sectional design. The study was conducted in Blora, Central Java, from June to July 2018.

\section{Population and Samples}

The target population were elderly people aged $>60$ years. The source population in this study were elderly aged 60 years in Blora, Central Java. A sample of 200 elderly was selected by snowball sampling.

\section{Study Variables}

The dependent variable was healthy ageing. The independent variables were religiosity, education, financial condition, nutrition status, and age.

\section{Operational Definition of Variables}

Religion was defined as the values of the teachings from God that guide people towards a goal in accordance with the wishes of certain teachings that play a positive role in mental and psychosocial wellbeing. It was measured by a questionnaire consisting of whether a person has faith (religion), how much religious influence in life, and the frequency of conducting religious activities. The measurement scale was continuous, but for the purpose of data analysis, it was transformed into dichotomous, coded o for poor and 1 for low.

Education was defined as last level of education that an individual has achieved. The data were measured by questionnaire. The measurement scale was categorical, coded o for <senior high school and 1 for $\geq$ senior high school. 
Journal of Epidemiology and Public Health (2019), 4(1): 30-36

https://doi.org/10.26911/jepublichealth.2019.04.01.04

The perception of financial condition was defined as a person's financial condition related to satisfaction with their income and ability to pay for health services. The data were measured by questionnaire. The measurement scale was continuous, but for the purpose of data analysis, it was transformed into dichotomous, coded o for poor and 1 for good.

Nutritional status was defined as the process of entering and processing food substances to the body that aims to produce energy which is used for doing activities. In this study, the nutritional status studied was food intake, weight loss, mobility, psychological stress, depression, and body mass index. The data were measured by questionnaire. The measurement scale was continuous, but for the purpose of data analysis, it was transformed into dichotomous, coded o for poor and 1 for good.

Age was defined as the calculation of the time that starts from the time of the study subjects was born until the time of data collection. The data were measured by questionnaire. The measurement scale was continuous, but for the purpose of data analysis, it was transformed into dichotomous, coded o for $<69$ years and 1 for $\geq 69$ years

Healthy ageing was defined as an aging process that stays healthy physically, socially and mentally so that it can remain prosperous throughout life and continue to participate in order to improve the quality of life as a member of society. The data were measured by questionnaire. The measurement scale was continuous, but for the purpose of data analysis, it was transformed into dichotomous, coded o for poor and 1 for good.

\section{Data Analysis}

The data were analyzed by multilevel analysis approach with Stata 13 program to determine the effect of independent variables on the dependent variables.

\section{Research Ethics}

The research ethics includes informed consent, anonymity, confidentiality, and ethical clearance. The ethical clearance in this study was carried out by the Ethical Cleareance Commission Team at the Sebelas Maret University Medical Faculty No. 115 / UNS27.6 / KEPK / 2018.

\section{RESULTS}

\section{Study Subjects Characteristics} Table 1. Study subject characteristics

\begin{tabular}{|c|c|c|}
\hline Variable & $\mathbf{n}$ & $\%$ \\
\hline \multicolumn{3}{|l|}{ Gender } \\
\hline Male & 69 & 34.5 \\
\hline Female & 131 & 65.5 \\
\hline \multicolumn{3}{|l|}{ Age } \\
\hline 60-74 years old & 156 & 78 \\
\hline 75-90 years old & 42 & 21 \\
\hline$>90$ years old & 2 & 1 \\
\hline \multicolumn{3}{|l|}{ Education } \\
\hline <senior high school & 100 & 50 \\
\hline$\geq<$ senior high school & 100 & 50 \\
\hline \multicolumn{3}{|l|}{ Occupation } \\
\hline Working & 52 & 26 \\
\hline Not working & 148 & 74 \\
\hline \multicolumn{3}{|l|}{ Smoking } \\
\hline Yes & 42 & 21 \\
\hline No & 158 & 79 \\
\hline \multicolumn{3}{|l|}{ Physical activity } \\
\hline Weak & 137 & 68.5 \\
\hline Strong & 63 & 31.5 \\
\hline \multicolumn{3}{|l|}{ Religiousity } \\
\hline Weak & 86 & 43 \\
\hline Strong & 114 & 57 \\
\hline \multicolumn{3}{|l|}{ Financial Condition } \\
\hline Poor & 92 & 46 \\
\hline Good & 108 & 54 \\
\hline \multicolumn{3}{|l|}{ Nutrition } \\
\hline Poor & 101 & 50.5 \\
\hline Good & 99 & 49.5 \\
\hline
\end{tabular}

Table 1 shows that the study subjects consisted of 69 people (34.5\%) elderly men and 131 people (65.5\%) elderly women. Most of the study subjects were at age 6074 years $(156,78 \%)$, did not work (148, $74 \%)$, did not smoke $(158,79 \%)$, and had weak physical activity (137, 68.5\%). Study 
subjects with high and low education level had the same composition of 100 people (50\%). As many as 114 elderly (57\%) had good religiosity, 108 (54\%) had high family income, and 101 elderly (50.5\%) had poor nutritional status.

\section{Multilevel Analysis}

The results of multilevel analysis was showed in Table 2. Based on Table 2, healthy ageing increases with strong religious belief $(b=6.57 ; 95 \% \mathrm{CI}=3.48$ to 9.66; $\mathrm{p}<0.001)$, higher education $(\mathrm{b}=7.43$; 95\% $\mathrm{CI}=3.69$ to $11.16 ; \mathrm{p}<0.001)$, good financial situation $(b=6.77 ; 95 \% \mathrm{CI}=3.30$

Table 2. The results of multilevel analysis on the effect of religiousity, education, financial situation, nutrition status, and on healthy ageing

\begin{tabular}{|c|c|c|c|c|}
\hline \multirow{2}{*}{ Variable } & \multirow{2}{*}{ b } & \multicolumn{2}{|c|}{$95 \%$ CI } & \multirow[b]{2}{*}{$\mathbf{p}$} \\
\hline & & Lower Limit & Upper Limit & \\
\hline \multicolumn{5}{|l|}{ Fixed Effect } \\
\hline Religious Belief (strong) & 6.75 & 3.92 & 9.59 & $<0.001$ \\
\hline Education $(\geq \mathrm{HS})$ & 8.17 & 4.25 & 12.07 & $<0.001$ \\
\hline Perceived Financial Situation (good) & 6.46 & 2.86 & 10.07 & $<0.001$ \\
\hline Nutrition(good) & 6.79 & 3.75 & 9.83 & $<0.001$ \\
\hline Age ( $\geq 69$ years old $)$ & -3.07 & -6.36 & 0.22 & 0.068 \\
\hline Constants & 79.89 & 75.93 & 83.85 & \\
\hline \multicolumn{5}{|l|}{ Random Effect } \\
\hline \multicolumn{5}{|l|}{ Peer Group } \\
\hline Nutrition (good) & 6.80 & 0.19 & 240.03 & \\
\hline Perceived Financial Situation (good) & 5.16 & 0.16 & 1648.68 & \\
\hline Var (constants) & 15.81 & 4.23 & 59.12 & \\
\hline \multicolumn{5}{|l|}{ n Observation $=200$} \\
\hline \multicolumn{5}{|l|}{$\mathrm{n}$ of Peer Group $=10$} \\
\hline Log likelihood $=-749.72$ & & & & \\
\hline $\begin{array}{l}\text { LR test vs. linear regression, } p=0.003 \\
\text { ICC }=14.64 \%\end{array}$ & & 0.04 & 0.39 & \\
\hline
\end{tabular}

\section{DISCUSSIONS}

\section{The effect of religiousity on healthy ageing}

A study done by Francis et al. (2014) strengthen the explanation that people who were active in religious activities would feel happier than people who were passive in doing religious activities. Through religious activities, the elderly would get a better life.

Previous studies have shown that religious activity contributed to individual happiness (Adam, 2014; Maselko and Kubzansky, 2006; Sarpitaningtyas, 2012). to $10.23 ; \mathrm{p}<0.001$ ), and good nutritional status $(b=7.00 ; 95 \% \mathrm{CI}=3.89$ to 10.11 ; $\mathrm{p}<0.001)$.

Peer group showed had a strong contextual effect on healthy ageing among elderly with $\mathrm{ICC}=14.64 \%$. This indicator showed that the variation of elderly people in achieving healthy ageing was 14.64\% determined by variables at the peer group level. This score was greater than the standard $8-10 \%$ role of thumb size, therefore, the contextual effect shown from multilevel analysis was very important to be noted.
Being closer to God could provide a sense of comfort in facing the pressure in life and could provide better conditions and also protection in dealing with various problems regarding the calm and happiness of our life. As people get older, the tendency of negative feelings would also increase (Candra, 2012; Rafikasari, 2015). There were various ways that the elderly can do to obtain happiness. One of them was by increasing religiosity.

According to Azani (2012), psychological welfare was an individual condition 
Journal of Epidemiology and Public Health (2019), 4(1): 30-36

https://doi.org/10.26911/jepublichealth.2019.04.01.04

characterized by a feeling of happiness, having life satisfaction, and no symptoms of depression.

2. The Effect of Education on Healthy Ageing

The result of this study showed that there was an effect between education on healthy ageing. Elderly people who have high education were more likely to achieve Healthy Ageing compared to those who have lower education.

A study by Schollgen et al. (2010) stated thathigher education improved the elderly in getting better opportunities throughout the life including in old age. Elderly people with higher education were more likely to be healthy, more often feel satisfied with their lives, interested in life and welfare, and more socially active (WHO, 2003). The result of this study was in line with a study by Kadarwati, et al (2017) which stated that education has an indirect effect on Healthy Ageing.

High level of education was associated with longevity and the incidence of disease. Healthy living habits and access to health services were also related to healthy ageing. The level of education also allowed someone to get more opportunities in getting a higher job and income, and it can lead to increased self-confidence, high life satisfaction, and better health conditions in older age (White et al., 2015).

\section{The Effect of Perceived Financial Situation on Healthy Ageing}

The result of this study showed that there was an effect between financial situation on healthy ageing. Elderly with better financial conditions were more likely to achieve Healthy Ageing.

This was in line with a study by Hammig et al. (2013), which stated that high income allowed the elderly to get a better chance of using health facilities. Bad social and economic environment affected health throughout life. Communities with low social classes have a risk for 2 times of being susceptible to serious illness and have a low life expectancy (WHO, 2003).

A study entitled "Predictors of Healthy Ageing: Public Health Policy Target" showed that with a good financial condition, the elderly also get good service quality (Sowa et al., 2016).

\section{The effect of nutrition on healthy ageing}

The result of this study showed that there was a significant relationship between nutrition and healthy ageing. Good nutrition would help the elderly in achieving healthy aging. A good diet and food availability were the keys to achieve health and welfare. Non-varied foods could lead to malnutrition and deficiency diseases.

Prijanto (2015) mentioned that the increasing number of elderly people caused an enhancement in health problems of the elderly as a result of changes in various body functions related to the need for a good quality of life. Nutritional status has a major impact on the occurrence of disease in the elderly.

\section{The effect of peer group level on healthy ageing}

The results of the study showed that variations in healthy ageing were $14.56 \%$ determined by variables at the peer group level.

A study by Dai et al. (2012), showed that there was a significant relationship between peer group supportthat support from peers or neighbors was very important for the elderly because it made the elderly to have better opportunities to understand and sharedtheir experiences.

A study by Suwarni et al. (2018), showed that there was a positive relationship between strong peer groups support and good quality of life in the elderly. The existence or availability of other people who 
can be relied upon, who showed love and concern for the values held by individuals was a support for someone(Sarason et al,. 1983 in Karimah, 2017).

A study which aimed at knowing the relationship between social cohesion with the incidence of cognitive decline in an elderly community, conducted on 2,812 elderly (age 65 years old or older) for 12 years. The results of the study showed that elderly with good social attachments were more likely to have slow reduction of cognitive function (Turana, 2013).

Elderly who actively participated in social activities and interaction with other people, it was known to help in stimulating cognitive function and slow the occurrence of senility. Social activities and social attachments have been shown to affected cognitive function in the elderly. Research showed the effect of the extent of social activity to stimulate and maintain cognitive function. Social attachment (including the maintenance and fostering of various social relationships, as well as active participation in social activities) could prevent cognitive decline in the elderly.

\section{REFERENCES \\ $\overline{\text { Abikusno N (2013). Kelanjutusiaan Sehat }}$ Menuju Masyarakat Sehat untuk Segala Usia. Buletin Jendela Data dan Informasi Kesehatan: Semester 12013 , 25-28.}

Adams C (2014). Religious People Much Happier and Have More Life Satisfication than Others. Daily Mail. Diunduh dari http://dailymail.co.uk.

Alavinia SM, Burdorf A (2008). Unemployment and Retirement and Ill-Health: A Cross-Sectional Analysis Across European Countries. Int Arch Occup Environ Health : 82, 39-45.
Beard JR, Carvalho IA, Officer A, Thiyagarajan JA (2017). Bulletin World Health Organization. 95: 730-730A.

Benach J, Muntaner C, Emconet (2011). Employment and Working Conditions as Health Determinants. Geneva: World Health Organization.

Cao J, Rammohan A (2016). Social Capital and Healthy Ageing in Indonesia. BMC Public Health. 16, 631.

Chakravarty SR (2006). The Measurement of Social Exclusion. Review of Income and Wealth. 52(3): 377-397.

Didem EE, Filiz E, Gulnur S, Erdal B (2012). Local Decision Makers' Awareness of The Social Determinants of Health in Turkey: A Cross-Sectional Study. BMC Public Health: 12, 437.

Duplaga M (2016). Health Promotion and Prevention of Risk - Action for Seniors. Poland : Pro-Health 65+.

EU-OSHA, Cedefop, Eurofound, EIGE on ageing and demographic change. (2017). Towards Age-Freindly Work in Europe: A Life Course Perspective on Work and Ageing from EU Agencies. Luxemburg: EU-OSHA, Cedefop, Eurofound, EIGE on ageing and demographic change.

Francis LJ, Yablon YB, Robbins M (2014). Religion and happiness: A study among female undergraduate students in Israel. International Journal of International Journal of Jewish Education Research (IJJER). 7:77-92.

Fuchs J, Nave CS, Hinrichs T, Mergenthaler A, Stein J, Heller SGR, Grill E (2013). Indicators for Healthy Ageing - A Debate. International Journal of Environmental Research and Public Health. 10: 6630-6644.

Hammig O, Bauer GF (2013). The Social Gradient in Work and Health: A Cross-Sectional Study Exploring the Relationship between Working Condi- 
Journal of Epidemiology and Public Health (2019), 4(1): 30-36

https://doi.org/10.26911/jepublichealth.2019.04.01.04

tions and Health Inequities. BMC Public Health : 13, 1-13.

Handayani A (2010). Hubungan Kepuasan Kerja dan Dukungan Sosial dengan Persepsi Perubahan Organisasi. Insan. 12(3): 127-136.

Help Age International (2015). Ageing Population in Indonesia. Tersedia di http://ageingasia.org/ageing-population-indonesia/. Diakses pada 29 September 2017.

Isfandari S (2012). Quality of Life of Indonesian Senior Citizens: Living in Extended Family as A Determinant Factors of Mental Health Status. Buletin Penelitian Sistem Kesehatan: 15(2): 120-125.

Jang SN, Choi YJ, Kim DH (2008). Association of Socioeconomic Status with Successfull Ageing: Differences in The Components of Successfull Ageing. J. biosoc.Sci. 41: 207-219.

Kadarwati, Soemanto RB, Murti B (2017). The influence of Family support, Social Capital, Self Eficacy, Education, Employment, Income and Residential status on the Quality of Life Among Elderly in Salatiga, Central Java. Journal of Epidemiology and Public Health (2017), 2(1): 58-69.
Laksono AD, Rachmawaty T (2013). Tantangan Determinan Sosial Kesehatan Ibu dan Anak di Indonesia. Research Gate : 1-18.

Lima MG, Barros MBA, Cesar CLG, Goldbaum M, Carandina L, Ciconelli RM (2009). Health Related Quality of Life Among The Elderly: A PopulationBased Study Using SF-36 Survey. Cad. Saude Publica, Rio de Janeiro. 25(10): 2159-2167.

Malderen LV, Mets T, Vriendt PD, Gorus E (2013). The Active Ageing-Concept Translated to The Residential LongTerm Care. Quality of Life Research. 22: 929-937.

Marc LG, Raue PJ, Bruce ML (2008). Screening Performance of the Geriatric Depression Scale (GDS-15) in a Diverse Elderly Home Care Population. Am J Geriatr Pcychiatry. 16(11): 914-921.

Marmot M, Allen JJ (2014). Social Determinants of Health Equity. American Journal of Public Health. 104(S4):

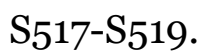

Mokdad AH, Remington PL (2010). Measuring Health Behaviour in Populations. Preventing Chronic Disease. 7(4): 1-7. 